\title{
Identifying and addressing sustainable pasture and grazing management options for a major economic sector - the north Australian beef industry
}

\author{
NEIL D. MACLEOD ${ }^{1}$, JOE C. SCANLAN ${ }^{2}$, LESTER I. PAHL ${ }^{2}$, GISELLE L. WHISH ${ }^{2}$ AND ROBYN A. COWLEY ${ }^{3}$ \\ ${ }^{1}$ CSIRO Ecosystem Sciences, Brisbane, Qld, Australia. www.csiro.au \\ ${ }^{2}$ Department of Agriculture, Fisheries and Forestry, Toowoomba, Qld, Australia. www.daff.qld.gov.au \\ ${ }^{3}$ Department of Resources, Katherine, NT, Australia. www.resources.gov.au
}

Keywords: Simulation modeling, grazing systems, stocking rate, economics, range condition, beef cattle.

\begin{abstract}
Sustainable use of Australia's northern grazing lands is a long-standing issue for management and policy, heightened by projections of increased climatic variability, uncertainty of forage supplies, vegetation complexes and weeds and diseases. Meat \& Livestock Australia has supported a large study to explore sustainable grazing management strategies and increase the capacity of the sector to address climate change. Potential options were explored by bio-economic modeling of 'representative' beef enterprises defined by pastoralists and supported by regional research and extension specialists. Typical options include diversification, infrastructure, flexible stocking rates, wet season resting and prescribed fire. Concurrent activities by another team included regional impact assessments and surveys of pastoralists' understanding of and attitudes towards climate change and adaptive capacity. The results have been widely canvassed and a program of on-ground demonstrations of various options implemented. The paper describes the structure of this program and highlights key results indicating considerable scope to address sustainability challenges.
\end{abstract}

\section{Resumen}

El uso sostenible de las pasturas en el norte de Australia, mayormente sabanas arboladas, es un tema de manejo y política de larga data, agudizado por las proyecciones de incremento de la variabilidad climática, la incertidumbre en el suministro de forrajes, lo complejo de la vegetación, las malezas y las enfermedades. Meat \& Livestock Australia, una organización de ganaderos australiana, ha apoyado un amplio estudio para explorar estrategias de manejo sostenible y aumentar la capacidad del sector para abordar los efectos del cambio climático. Las opciones potenciales se exploraron mediante el modelamiento bioeconómico de empresas ganaderas 'representativas', definidas por los productores con el apoyo de investigadores y extensionistas regionales. Las opciones típicas incluyen diversificación, infraestructura de las pasturas, carga animal flexible, descanso del pastoreo durante la época de lluvias y quemas controladas. Actividades simultáneas desarrolladas por otro equipo de trabajo incluyeron evaluaciones del impacto regional y encuestas sobre la percepción y actitud de los ganaderos respecto al cambio climático y su capacidad de adaptación. Los resultados han sido ampliamente divulgados y un programa demostrativo de varias opciones fue puesto en marcha. En el documento se describe la estructura de este programa y se resaltan los resultados más importantes los cuales indican un amplio margen para hacer frente a los desafíos de sostenibilidad.

\section{Introduction}

The north Australian grazing lands span $\sim 2.3 \mathrm{Mkm}^{2}$ and carry $\sim 14 \mathrm{M}$ cattle. Resource heterogeneity, climatic

Correspondence: Neil D. MacLeod, CSIRO Ecosystem Sciences, Brisbane, Qld 4001, Australia.

Email: neil.macleod@csiro.au variation and poor grazing management have caused landscape degradation and reduced ecological services (Tothill and Gillies 1993) and much research has been invested in exploring sustainable management practices. In 2009 Meat \& Livestock Australia initiated the Northern Grazing Systems (NGS) project, to identify and extend sustainable herd and land management strategies for 9 major bio-regions, involving: (1) scientific reviews 
of past research; (2) regional pastoralist workshops to explore options and define 'representative enterprises' for modeling; (3) bio-economic modeling of the impacts the most promising 'best bet' options have on landscape degradation and production, under current and projected climate regimes; and (4) applied testing and extension of the 'best-bet' options. Concurrent activities included assessments of regional impacts and pastoralists' understanding of and attitudes to climate change and adaptive capacity (Stokes et al. 2012). The bio-economic modeling component explored the production, resource condition and financial implications of northern beef enterprises adopting more promising strategies that were revealed through the science review and pastoralist workshop phases. Simulation of these strategies combined a pasture and animal production model (GRASP) with a dynamic beef herd economic model (ENTERPRISE) calibrated to mimic representative beef enterprises defined by the regional workshops.

Four herd and pasture management strategies were explored in each region: (a) Stocking rates - fixed versus variable stocking rates; (b) Wet season pasture spelling systems - variable paddock rotations, spelling commencement and duration; (c) Prescribed fire for woody vegetation control - fire regimes of varying frequency, starting tree basal area etc.; and (d) Infrastructure - strategic expansion and location of stock waters, fencing etc. The modeling process is illustrated with a comparison of fixed and variable stocking rates strategies in the Fitzroy River region using a hypothetical farm located at Duaringa, Queensland.

\section{Methods}

\section{Overall NGS Process}

The NGS strategy incorporated the following aspects: (1) Formally review past research conducted across northern Australia to identify central themes and underlying principles that might be applied to management in the regions (McIvor et al. 2010); (2) Present strategies built around these themes at workshops of pastoralists, research and extension specialists in 9 agro-ecological regions, and those of interest listed for further exploration by simulation modeling of a representative beef enterprise defined for each region; (3) Application of bio-economic modeling to the selected strategies of interest; (4) Canvass modeling results at a second series of regional workshops and refine the scenarios where appropriate. The workshop outcomes in conjunction with the initial research review provided insight into further research to fill knowledge gaps or follow through on technical questions raised by the modeling effort; and (5) Conclusions from the workshops and modeling process were used to support on-property confirmation and demonstration trials based on the most promising herd and pasture management strategies for each region.

\section{Bio-Economic Modeling}

The modeling method and outcome are illustrated for 1 of the 9 regions, Fitzroy in central Queensland [full details of all regions are presented in Scanlan and McIvor (2010)]. A representative beef enterprise, defined at a workshop in Emerald in April 2009, is characterized as a 10500 ha property located near Duaringa $\left[23.71^{\circ} \mathrm{S}\right.$, $149.67^{\circ} \mathrm{E}$; $94 \mathrm{~m}$ asl; average annual rainfall (1885-2006) $=704 \mathrm{~mm}$, average annual rainfall (1980-2006) = $613 \mathrm{~mm}$ ] comprising 15 paddocks of native and sown pastures carrying $~ 1200$ breeding cows and turning off $\sim 600 \mathrm{~kg} / \mathrm{head}$ slaughter bullocks. Starting paddock condition varies from ' $\mathrm{B}$ - good' to ' $\mathrm{C}$ - poor and degraded' as rated against a 4-category system (Chilcott et al. 2003).

Pasture yield, annual carrying capacity and animal liveweight gain for the management practices under review are estimated for each paddock using the GRASP pasture simulation model (McKeon et al. 1990). Annual liveweight gain $(\mathrm{kg} / \mathrm{head} / \mathrm{yr})$ is simulated as a function of forage utilization and growing season length (green days). Land condition impact is assessed through a combination of \% perennial grasses in the pasture sward and grass basal area (Scanlan et al. 2011). Projected liveweight gain and stocking rate for each paddock are input to the ENTERPRISE herd economic model (MacLeod and Ash 2001), that allocates the herd across the 15 paddocks. Herd fertility and mortality rates, which underpin the herd population dynamics, are estimated from the liveweight gain projections using regression equations based on herd records from Swans Lagoon Research Station (MacLeod and Ash 2001). ENTERPRISE projects total animal numbers by sex and age class, animal turnoff rates for each year of a simulation trial and a range of profit metrics, including gross margins, net profit and ranges for these measures. Simulations of 25 years were run using climatic data for Duaringa from 1986 to 2010.

\section{Modeling example - fixed versus variable stocking rates}

Declining pasture condition is typified by reductions in $\%$ palatable perennial grasses, increases in annual 
grasses and forbs and also the amount of bare ground (McIvor and Orr 1991). Adopting conservative or flexible stocking rates is argued to be critical for sustainable pasture management (McKeon et al. 1990). The example simulation compares a fixed stocking rate strategy with 2 strategies that allow variation in annual stocking rate in response to changing seasonal conditions and associated forage availability. The 'safe' fixed stocking rate is set for each paddock at the assessed long-term safe utilization rate $(\sim 20-25 \%)$ of standing pasture dry matter at the end of the growing season. The 2 variable strategies are defined as seasonally responsive and constrained variation. The seasonally responsive strategy has a stocking rate in each paddock set each year according to a safe utilization rate of standing dry matter $(20-25 \%)$ at the end of the growing season and remains unchanged for the following 12 months. The constrained variation strategy allows no more than a $10 \%$ increase or $20 \%$ decrease in stocking rate between individual years subject to annual safe utilization limits and an absolute limit of $20 \%$ above or $40 \%$ below the stocking rate that is set at the start of the simulation period. Comparisons were made of simulation outputs for each paddock over the 25-year simulation period.

\section{Results}

The representative enterprise included 7 land/vegetation types in 15 paddocks, 9 of which were in B condition and 6 in $\mathrm{C}$ condition. The GRASP simulation results are presented for one of the 15 paddocks and its constituent land class - a cleared paddock comprising brigalow- blackbutt (Acacia harpophylla-Eucalyptus cambageana) vegetation type in $\mathrm{B}$ condition at the commencement of the simulation.

\section{Stocking rate}

The fixed stocking rate is set in accordance with the safe utilization rate estimated for the average rainfall of the simulation run. The flexible stocking rates fluctuate within the limits defined above. The 2 variable stocking rate strategies decreased the carrying capacity of the paddock by the end of the simulation period (Figure 1). This is largely because of pasture damage caused by holding excessive numbers of stock on pastures when good rainfall years are followed by poor rainfall years (Scanlan and McIvor 2010). The fixed stocking rate by definition did not change over the simulation period.

\section{Pasture condition}

The impact of stocking rates on pasture condition as measured by $\%$ composition of perennial grasses in the sward is presented in Figure 2. The seasonally adjusted stocking rate strategies can potentially reduce cattle numbers when forage availability is low, and reduce overgrazing risk. However, all 3 strategies overshot animal numbers early in the simulation period, with subsequent decline in $\%$ perennials (Figure 1). The more restrictive constrained strategy, unlike the seasonally constrained strategy, prevented sufficient reduction in cattle numbers to stop serious pasture damage, which led to a longer recovery at the end of the simulation (Figure 2).

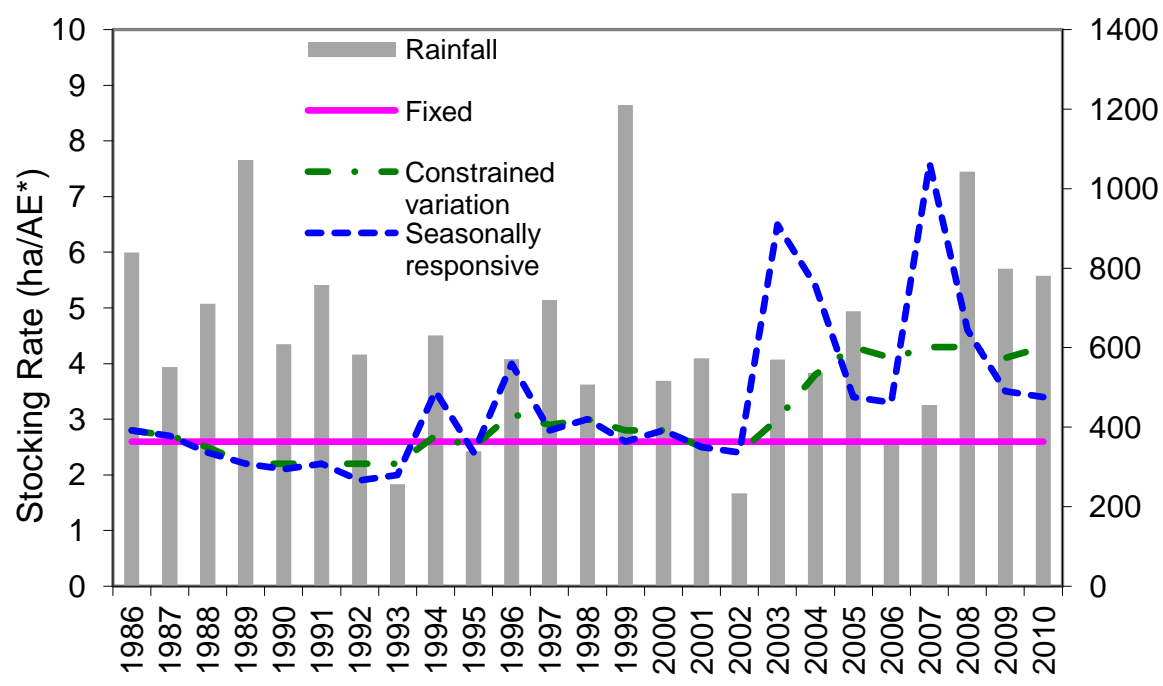

Figure 1. Projections of annual carrying capacity for 3 stocking rate strategies on B condition cleared brigalow-blackbutt pasture, Duaringa (1986-2010). *1 Adult Equivalent (AE) $=455 \mathrm{~kg}$ beast. 


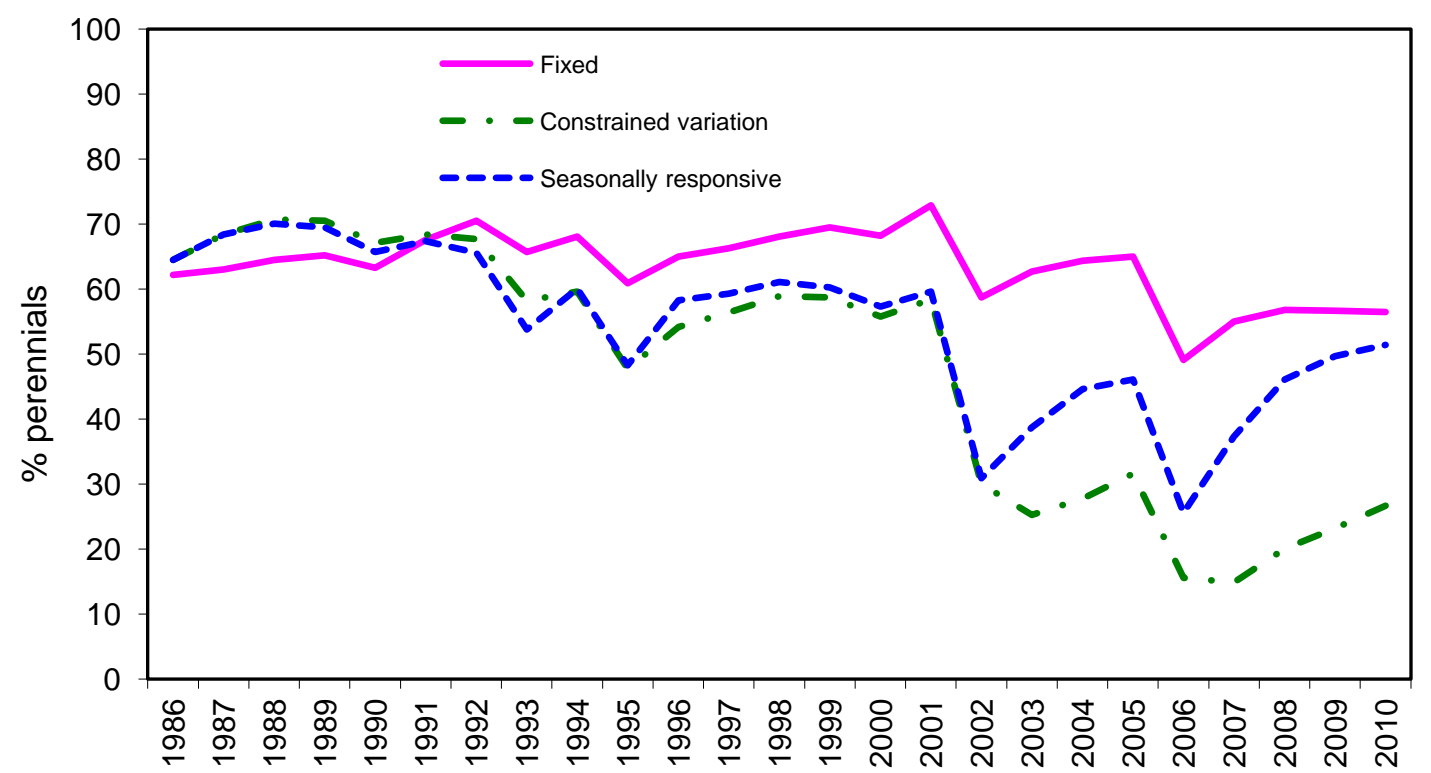

Figure 2. Projections of \% perennials for 3 stocking rate strategies on B condition cleared brigalow-blackbutt pasture, Duaringa (1986-2010).

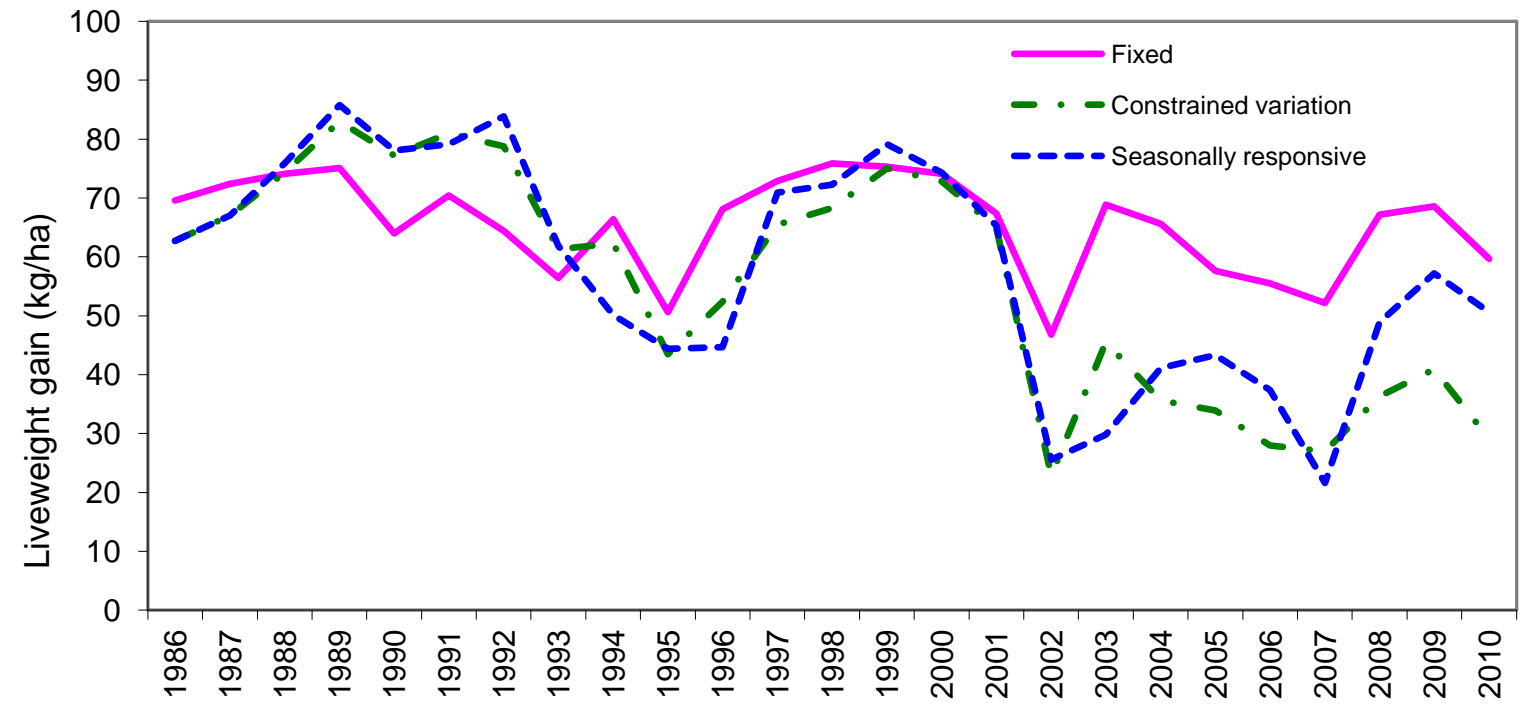

Figure 3. Projections of liveweight gain per hectare for 3 stocking rate strategies on B condition cleared brigalow-blackbutt pasture, Duaringa (1986-2010).

\section{Animal production}

The 'safe' fixed stocking rate maintained pasture condition better than the variable strategies, producing higher average liveweight gains per hectare at the end of the period (Figure 3). The variable stocking strategies generally yielded higher gains at the beginning of the simulation, when pasture conditions improved (Figures 2 and 3). The seasonally responsive strategy outperformed the constrained variation strategy as ani- mal numbers were adjusted more rapidly in the face of changing conditions.

\section{Profit}

The safe fixed stocking rate strategy produced the highest annual average profit (total revenue minus total costs), followed by seasonally responsive and constrained variation strategies (Table 1). Fixed stocking had the highest minimum profit and the fewest years when profit 
Table 1. Estimated annual total profit (AU\$) for 3 stocking rate management strategies on the representative Duaringa enterprise (mean values for simulation period 1986-2010).

\begin{tabular}{lccc}
\hline & Fixed stocking rate & $\begin{array}{c}\text { Constrained } \\
\text { variation }\end{array}$ & $\begin{array}{c}\text { Seasonally } \\
\text { responsive }\end{array}$ \\
\hline Average & $\$ 204401$ & $\$ 77370$ & $\$ 135536$ \\
Minimum & $-\$ 64425$ & $-\$ 183421$ & $-\$ 313983$ \\
Maximum & $\$ 490670$ & $\$ 346240$ & $\$ 743838$ \\
Negative years & 3 & 8 & 11 \\
\hline
\end{tabular}

was negative. As stocking rate flexibility increased, the number of years when annual profit was negative tended to increase.

\section{Discussion}

The results are presented to illustrate the utility of the NGS approach. For the Duaringa example, the projected responses for carrying capacity, resource condition, animal production and profitability for the 3 stocking rate options revealed that the 'extremes' of the flexibility strategies were generally the most profitable under the climatic conditions between 1986 and 2010. The results are highly context-dependent and reflect a combination of the stocking rate strategies, land/vegetation types, land condition and climatic conditions at the time of the simulation trial. The results from each of the regional simulations were endorsed at subsequent workshops and the insights for the various strategies, i.e. stocking rates, seasonal resting, prescribed fire, have been incorporated into local extension materials and on-farm demonstrations. The herd and land management strategies have been explored under different climatic sequences in the 9 regions, including under projected climate change, to seek scope for enhanced forecasting to inform management.

\section{Conclusion}

The NGS process which includes the simulation of 'representative' grazing enterprises constructed around a process of science review and local pastoralist consensus offers considerable scope for defining sustainable land management practices with both economic potential and high levels of producer ownership. The results presented offer only a limited insight into the full potential of the models to explore management options in detail. The simulation modeling approach offers a useful alternative to trials for screening large numbers of management options and strategies for future application in research or practice.

\section{Acknowledgments}

The NGS project was funded as Meat \& Livestock Australia project B.NBP.0578. The assistance of DAFF beef extension officers and landholders from the Fitzroy region is appreciated.

\section{References}

Chilcott CR; McCallum BS; Quirk MF; Paton CJ. 2003. Grazing land management education package workshop notes - Burdekin. Meat \& Livestock Australia Limited, North Sydney, NSW, Australia.

MacLeod ND; Ash AA. 2001. Oceans to Farms Project Report No. 6. CSIRO (Commonwealth Scientific and Industrial Research Organisation), Brisbane, Qld, Australia.

McIvor JG; Orr DM. 1991. Sustaining productive pastures in the tropics. 3. Managing native grasslands. Tropical Grasslands 25:91-97.

McIvor JG; Bray SG; Grice AC; Hunt LP. 2010. Grazing management guidelines for northern Australia: Scientific rationale and justification. In: McIvor JG, ed. Final Report MLA Project NBP.0579. Meat \& Livestock Australia Limited, North Sydney, NSW, Australia. p. 10-205.

McKeon GM; Day KA; Howden SM; Mott JJ; Orr DM; Scattini WJ; Weston EJ. 1990. Northern Australian savannas: Management for pastoral production. Journal of Biogeography 17:355-372.

Scanlan JC; McIvor JG. 2010. Enhancing adoption of best practice grazing management in northern Australia. Final Report: Caring for Our Country Project OG084273. Meat \& Livestock Australia Limited, North Sydney, NSW, Australia. .

Scanlan JC; Whish GL; Pahl LI; Cowley RA; MacLeod ND. 2011. Assessing the impact of pasture resting on pasture condition in the extensive grazing lands of northern Australia. In: Chan F; Marinova D; Anderssen RS, eds. Proceedings of MODSIM2011, 19th International Congress on Modelling and Simulation. Modelling and Simulation Society of Australia and New Zealand, Perth, WA, Australia . p. 877-883.

Stokes C; Marshall N; MacLeod N. 2012. Final Report MLA NBP Project 0617. Meat \& Livestock Australia Limited, North Sydney, NSW, Australia.

Tothill JC; Gillies C. 1993. The pasture lands of northern Australia. Their condition, productivity and sustainability. Occasional Publication No. 5. Tropical Grassland Society of Australia, Brisbane, Qld, Australia.

\section{(c)}

Tropical Grasslands-Forrajes Tropicales is an open-access journal published by Centro Internacional de Agricultura Tropical (CIAT). This work is licensed under a Creative Commons Attribution-NonCommercial-ShareAlike 3.0 Unported License. To view a copy of this license, visit http://creativecommons.org/licenses/by-nc-sa/3.0/ 
MacLeod ND; Scanlan JC; Pahl LI; Whish GL; Cowley RA. 2013. Identifying and addressing sustainable pasture and grazing management options for a major economic sector - the north Australian beef industry. Tropical Grasslands - Forrajes Tropicales 1:220-224.

DOI: $10.17138 / \mathrm{TGFT}(1) 220-224$

This paper was presented at the $22^{\text {nd }}$ International Grassland Congress, Sydney, Australia, 15-19 September 2013. Its publication in Tropical Grasslands - Forrajes Tropicales is the result of a co-publication agreement with the IGC Continuing Committee. Except for adjustments to the journal's style and format, the text is essentially the same as that published in: Michalk LD; Millar GD; Badgery WB; Broadfoot KM, eds. 2013. Revitalising Grasslands to Sustain our Communities. Proceedings of the $22^{\text {nd }}$ International Grassland Congress, Sydney, Australia, 2013. New South Wales Department of Primary Industries, Orange, NSW, Australia. p. 1643-1646. 